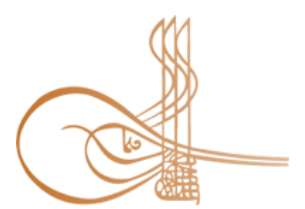

www.turkishstudies.net/history
Turkish Studies - Historical Analysis

eISSN: 2667-5552

Research Article / Araştırma Makalesi

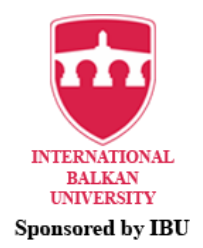

Sponsored by IBU

\title{
1935 Yılı Dış Politika Raporları Doğrultusunda Türkiye'nin Uluslararası Gelişmelere Bakışı
}

Turkey's Perspective on International Events in Accordance with Foreign Policy Reports of 1935

\author{
Melih Duman*
}

\begin{abstract}
This study examines the reports on evaluation of Turkish foreign policy prepared by three statesmen in 1935. In the study, The Assessments Of Foreign Affairs Secretary General Numan Menemencioğlu and Deputy Secretary General Ali Türkgeldi and of the Prime Minister İsmet İnönü were analyzed in terms of Turkish foreign policy based on the events that took place in the world in 1935. The purpose of this study is to present perception of Turkey's foreign policy in the context of pre-World War II developments occurring in the World by the archive documents obtained through documentary scan method. It was seen that Turkey carefully addressed the Eurocentric developments in terms of its foreign policy due to Italy's attack to Ethiopia and creating security concerns in Mediterranean and Balkans. Other developments occurring in the world apart from Mediterranean, the Balkans and Ethiopia developments were also among the issues tackled in terms of Turkey's foreign policy. The interconnected and disconnected assessments of Ali Türkgeldi, Numan Menemencioğlu and İsmet İnönü contain very important data as they indicate the focal points of Turkish foreign policy. The issues, which Turkey has a high sensitivity on, such as security of Mediterranean and Balkans, the issue of Ethiopia, rivalry between Germany and England, alliances occurred in the Europe etc. were included in the reports as topics indicating the red lines of Turkey before the Second World War. In this context, study examines the perceptions of Turkey's foreign policy among the developments in the world in 1935 in the process of going to the Second World War and evaluates foreign policies created by Turkey against the developments.
\end{abstract}

Structured Abstract: After the Treaty of Lausanne, the founding treaty of the Republic of Turkey, was signed in 1923, Turkey, which considerably realized the decisions of Misak-1 Milli ( The National Oath), put the war period behind and passed the diplomacy period in foreign policy when matters remaining unsolved in the Treaty of Lausanne were solved. Turkish foreign policy, which no longer progressed in parallel with the war, had tried to solve the problems that could not be solved in Lausanne to the extent permitted by diplomacy, and was finalized to a large extent. In the period that was referred to as the interwar period, as Turkey had focused on internal political developments in the main, it had also started to closely follow up the changes occurred in Europe as of 1930's.

Turkish foreign policy followed Italy and Germany, which were dissatisfied with the results of the World War I and took action to change these conditions, and their policies. In terms of Turkish foreign policy, the developments in Europe and the western border of Turkey had become very important for Balkans before World War II. In this period, Turkish foreign policy makers, who took action to solve the security problem, had placed the process that was initiated by Germany in Europe and the aggressive policies initiated by Italy,

\footnotetext{
${ }^{*}$ Dr. Öğr. Üyesi, Aksaray Üniversitesi, İletişim Fakültesi, Radyo Televizyon Sinema Bölümü Assistant Professor, Aksaray University, Faculty of Communication, Radio Television and Cinema Department ORCID 0000-0001-6861-615X melihduman1@gmail.com

Cite as/ Atıf: Duman, M. (2020). 1935 yılı dış politika raporları doğrultusunda Türkiye'nin uluslararası gelişmelere bakış1. Turkish Studies - History, 15(3), 913-930. https://dx.doi.org/10.47846/TurkishStudies.45584

Received/Geliş: 05 August/Ağustos 2020

Accepted/Kabul: 20 September/Eylül 2020

Copyright (C) INTAC LTD, Turkey
} 
primarily Ethiopia and the Mediterranean, in the lead in terms of priority. Within this scope, the foreign policy reports written by the authorities of Turkish Ministry of Foreign Affairs, Ali Türkgeldi and Numan Menemencioğlu, and Primer Minister, İsmet İnönü, who made assessments for a few months in 1935 revealed the concerns and distress of Turkey before W W II. The fact that the reports were not written to be shared with the public had ensured that the reports had an objective attitude. In this sense, events occurring in Europe and in the world were evaluated in terms of the priorities of Turkish foreign policy. Under the light of the archive data obtained as a result of the documentary literature review, the foreign policy of Turkey before the Second World War was evaluated as specific to 1935. The meaning of developments experienced in 1935 for Turkish foreign policy was addressed based on expectations and concerns of Turkey and they became the subjects seeking an answer.

The study was discussed over the three reports. First one was the assessment that was written by Ali Türkgeldi as the universal agent of the clerk of Department of State, which was also the volumetrically largest report. In his report, Ali Türkgeldi examined the developments under titles of French - Italian and French English treaties; English - German Conflict; Ethiopia Issue; Aviation Pact; Oriental Entente; Tuna Pact; Habsburg Problem; Turkey and Balkan States; Internal political developments in Europe; Political and commercial relations of Turkey. The sixty - page report of Ali Türkgeldi showed that Turkish foreign policy had been following up and analyzing every development in Europe prior to WW II down to the last detail. The second one was the report written by the Universal Clerk of the Department of State, Numan Menemencioğlu, in addition to the report of Ali Türkgeldi. In his report, Menemencioğlu accepted the report of Türkgeldi to a large extent, but he brought forward a few different points. Numan Menemencioğlu brought following matters to the fore except for the report of Türkgeldi; Relations of Soviet Russia with Western Countries; Possible polarization to be caused by Ethiopia Issue in; Evaluation of Ethiopia Issue by England for Straits and Aegean Islands of Turkey; Italian - German Alliance; Balkan Alliance; Relations of Italy with Balkan States; and German - Turkish Relations. The last report, on the other hand, was the report of Prime Minister İsmet İnönü, which was handled independently from the first two reports, and which also had a limited scope, regarding the Italy- Ethiopia issue. In a period when the states became polarized rapidly in Europe in accordance with their interests and aggression increased inside and outside Europe, Turkey assessed the events in Europe and endeavored to determine Turkish Foreign Policy required to be followed with three reports.

The issues specified in the foreign policy reports of Turkey in 1935 had developed the main steps of policy to be ensued by Turkey before and during the Second World War. Under the light of the findings, the study reveals with the year 1935 of Turkish foreign policy in the process towards the Second World War and reveals the priorities and expectations of the foreign policy.

Keywords: Ali Türkgeldi, Foreign Policy, İsmet İnönü, Numan Menemencioğlu, Political History

Öz: Bu çalışma 1935 yılında üç devlet adamının hazırladığı Türk dış politikası hakkında değerlendirmeler içeren raporları ele almaktadır. Çalışmada Dışişleri Bakanlığı Genel Sekreteri Numan Menemencioğlu ile Genel Sekreter Vekili Ali Türkgeldi ve Başbakan İsmet İnönü’nün değerlendirmeleri, 1935 yılında dünyada meydana gelen olaylar ekseninde Türk dış politikası açısından analiz edilmiştir. Bu çalışmanın amacı, belgesel kaynak tarama metodu aracılığıyla elde edilen arşiv belgeleri ile Türkiye'nin İkinci Dünya Savaşı öncesindeki dış politika algısını dünyada meydana gelen gelişmeler bağlamında ortaya koymaktır. İtalya'nın Habeşistan'a saldırması ve Akdeniz ile Balkanlarda güvenlik endişesi meydana getirmesi karşısında, Türkiye'nin Avrupa merkezli olarak gelişmeleri dış politikası açısından dikkatle ele aldığı görülmüştür. Akdeniz, Balkanlar ve Habeşistan gelişmeleri dışında dünyada meydana gelen diğer gelişmeler de Türkiye'nin dış politikası açısından ele aldığı meseleler arasında yer almıştır. Ali Türkgeldi, Numan Menemencioğlu ve İsmet İnönü’nün birbirleriyle bağlantılı ve bağlantısız değerlendirmeleri, Türk dış politikasının odak noktalarını belirtmeleri sebebiyle oldukça önemli veriler içermektedir. Türkiye'nin hassasiyetinin yüksek olduğu Akdeniz ve Balkanların güvenliği, Habeşistan Meselesi, Almanya - İngiltere rekabeti, Avrupa'da meydana gelen ittifaklar gibi konular, Türkiye'nin II. Dünya Savaşı öncesindeki kırmızı çizgilerini ortaya koyan konular olarak raporlarda yer almıştır. Bu çerçevede çalışma, II. Dünya Savaşı'na gidilen süreçte Türkiye'nin dış politika algılamalarını 1935 yılında dünyada meydana gelen gelişmeler içerisinde ele almakta ve gelişmeler karşısında Türkiye'nin dış politikasını değerlendirmektedir.

Anahtar Kelimeler: Ali Türkgeldi, Dış Politika, İsmet İnönü, Numan Menemencioğlu, Siyasi Tarih 


\section{Giriş}

Lozan Antlaşması'nın imzalanması sonrasında, uluslararası alanda resmi olarak tanınmanın etkisiyle birlikte Türkiye, dış politikasında Lozan'da çözülemeyen sorunlara yönelmiştir (Hale, 2003: 48-50). Lozan sonrası Türkiye'nin en yakın ilişki kurduğu devletlerden birisi Sovyet Sosyalist Cumhuriyetler Birliği (SSCB) olmuştur. 1923'ten 1936 y1lına kadar dış politikasında Sovyet Rusya'y1 gözeten Türkiye, 1930'lu y1llarla birlikte Almanya ve İtalya merkezli olarak dünyada meydana gelen gelişmelerden etkilenmeye başlamıştır. İtalya'nın özellikle 1934 yılında Asya ve Afrika'ya yönelik yaptığı açıklamalar, Türkiye'nin tehdit algılamasına yol açmıştır. Kısa süre içerisinde İtalya, Türkiye'ye karşı bir emel beslemediğini bildirmişe de 1935 yılında Habeşistan'a saldırması, Berlin-Roma hattını kuvvetlendirmesi Akdeniz ve Balkanlarda bir güvensizlik meydana getirmiştir (Soysal, 1999: 293-294).

Dış politikasında anti revizyonist bir çizgi izleyen Türkiye, artan tehdit karşısında bölgesel paktlar kurulması ve anti revizyonist Batılı devletlerle ittifak arayışı içerisine girilmesi yönünde politika takip etmeye başlamıştır (Berber, 2008: 237-246). Doğu Akdeniz başta olmak üzere yakın coğrafyasında güvenlik endişesi yaşayan Türkiye (Uçarol, 2000: 573), bu bunalımı aşmak üzere dünyada meydana gelen olayları ve devletlerin birbirleriyle olan ittifakları karşısında gelişmeleri, öncelikli çıkarları açısından takip eden yeni bir dış politika refleksi geliştirme eğilimi içerisinde olmuştur. Bu doğrultuda çalışma, Almanya ve İtalya merkezli olarak dünyada bir takım değişmelerin yaşandığı, II. Dünya Savaşı öncesindeki dönemde Türk devlet adamlarının 1935 yılında kaleme aldıkları raporlar doğrultusunda Türk dış politikasının uluslararası gelişmeleri nasıl değerlendirdiğini, dünyada meydana gelen kamplaşmaya karşı nasıl bir dış politika projeksiyonu sunduklarını ele almaktadır. Cumhurbaşkanlığı Devlet Arşivleri Başkanlığı Cumhuriyet Arşivi belgelerine dayanan çalışma, metedolojik olarak özellikle çalışmanın konusunu teşkil eden Numan Menemencioğlu, Ali Türkgeldi ve İsmet İnönü'nün dış politika raporlarına dayanmaktadır. 1935 yılı spesifik bir tarihe işaret etmekle birlikte Türk dış politikası açısından II. Dünya Savaşı öncesinde Avrupa'da meydana gelen olayların değerlendirildiği ve oldukça önemli gelişmelerin yaşandığı bir yıl olmuştur. $\mathrm{Bu}$ doğrultuda 1935 yılında, Dışişleri Bakanlığı Genel Sekreteri Numan Menemencioğlu, Genel Sekreter Vekili Ali Türkgeldi ve Başbakan İsmet İnönü tarafından dikkat çeken üç rapor kaleme alınmıştır. 1935 yılında Türk dış politikasının hassasiyetlerini gösteren üç değerlendirmenin kaleme alınmış olması, Türkiye açısından yaşanan olaylara nasıl bakıldığını ve olayların nasıl ele alındığını göstermektedir. Raporlar, dönemin gelişmeleri ışı̆̆ında Türkiye'nin dünya meseleleri ve bunlar karşısında gelişen ittifaklara bakışını ortaya koymaktadır. Çalışma bu eksende üç devlet adamının raporları doğrultusunda; II. Dünya Savaşı öncesinde meydana gelen gelişmeler karşısında Türk dış politikasını analiz etmektedir. Çalışma belgesel kaynak tarama metoduyla elde edilen arşiv belgeleri doğrultusunda, Türkiye'nin II. Dünya Savaşı'na gidilen süreçteki konumunu devlet görevlilerin resmi bakışı ekseninde değerlendirmektedir.

Giriş, “Türk Dış Politikası (1923-1938)”, “Ali Türkgeldi’nin 1935 Y1lı Raporu”, "Numan Menemencioğlu'nun Değerlendirmesi”, "Başbakan İsmet İnönü’nün Habeşistan Meselesi Değerlendirmesi" ve Sonuç bölümleri şeklinde ele alınan çalışmada, "Türk Dış Politikası (19231938)" bölümünde II. Dünya Savaşı öncesindeki Türk dış politikası genel hatlarıyla değerlendirilmiştir. "Ali Türkgeldi'nin 1935 Yı1ı Raporu”, bölümünde makalenin temel konusunu oluşturan üç rapordan ilki olan Ali Türkgeldi'nin raporu ele alınmıştır. Altıııs sayfalık hacmiyle dikkat çeken raporun, Avrupa'daki gelişmelere odaklandığı görülmüştür. Avrupa devletlerinin birbirleriyle yaptıkları antlaşmalar, Habeşistan Meselesi, Balkan Devletleri ile Türkiye'nin siyasi ve ticari ilişkileri gibi konuları ele alan rapor, öncelikle Avrupa merkezli gelişmelere yoğunlaşmıştır. Bu çerçevede Türkgeldi'nin raporunda, Almanya-İngiltere rekabeti ile İtalya-Habeşistan meselesine ayrı bir yer ayrıldığı görülmüştür. Gerek Alman-İngiliz rekabeti, gerekse Habeşistan Meselesi, aynı zamanda Türkiye'nin güvenlik endişeleri ile ilgili olması sebebiyle ayrıca dikkat edilen konular arasında olmuştur. 
"Numan Menemencioğlu'nun Değerlendirmesi” başlığı altında ele alınan üçüncü bölümde ise "Hariciye Vekâleti Kâtibi Umumisi" olan Numan Menemencioğlu'nun görüşleri ele alınmıştır. Menemencioğlu'nun raporu, Ali Türgeldi'nin raporuna ek olarak yazdığı analizleri içermektedir. Rapor, büyük bir oranda Türkgeldi'nin raporu ile paralel seyretmekle birlikte Türk dış politikası için yol gösterici olmak üzere, bir takım dikkat çekici farklı değerlendirmelerde bulunmuştur. Gerek Türkgeldi'nin gerekse Menemencioğlu'nun raporlarında, Türkiye'nin II. Dünya Savaşı sırasında izleyeceği politikalara yönelik tavsiyelerde bulunulduğu görülmüştür. Çalışma kapsamında "Başbakan İsmet İnönü’nün Habeşistan Meselesi Değerlendirmesi” başlığı altında ele alınan üçüncü rapor ise Başbakan İsmet İnönü’nün Dışişleri Bakanı Tevfik Rüştü Aras'la yaptığı görüşmeler sonucunda, İtalya konusunda kaleme aldığı değerlendirme olmuştur. İnönü'nün raporu, daha dar kapsamlı olmakla birlikte diğer iki raporu destekler mahiyette Türkiye açısından İtalya-Habeş meselesine odaklanmıştır.

Bu doğrultuda çalışma Türkgeldi, Menemencioğlu ve İnönü'nün analiz ve raporları ekseninde, II. Dünya Savaşı'na gidilen süreçte Türk dış politikasının 1935 yılını ele almakta ve dış politikanın öncelikleri ile beklentilerini ortaya koymaya çalışmaktadır.

\section{Türk Dış Politikası (1923-1938)}

Türk dış politikasında Atatürk Devri olarak bilinen 1919-1938 yılları arasındaki dönem iki kısımda tasnif edilebilir (Gönlübol \& Sar, 1997: III). Milli Mücadele dönemi olarak ifade edilen ilk dönem, Mustafa Kemal Paşa'nın Samsun'a ayak bastığı 1919 tarihiyle başlamakta ve Lozan Antlaşması ile sona ermektedir. William Hale bu dönemi "Diplomasi, Savaş ve Barış" olarak adlandırmakta ve süreci 1918 yılı ile başlatmaktadır (2003: 37). Kurtuluş Savaşı'nın Milli Mücadele içerisinde yürütüldüğü bu ilk dönemde, dış politikayı belirleyen temel husus savaşılarak elde edilen diplomatik zafer olmuştur. Var olma mücadelesi olan Milli Mücadele, zaferler kazanıldığı ölçüde dış politika yapmaya imkân vermiştir. Savaşın neticesinde elde edilen en önemli diplomatik zafer ise 1923'te imzalanan Lozan Antlaşması olmuştur (Bayur, 1995: 151). Hale, ikinci dönemi ise “Uzlaşmalar ve Pürüzler Dönemi 1923-39” olarak isimlendirmiştir. Hale göre, Lozan Antlaşması'nın imzalanmasıyla birlikte Milli Mücadele hareketi, en kritik sınavı geçmiş ve sahip olamadığı güvenliğe nihayet kavuşmuştur. Uluslararası alanda resmi olarak tanınan Ankara Hükümeti, 29 Ekim 1923 'te Cumhuriyetin ilanı ile birlikte artık Türkiye Cumhuriyeti'nin sağladığı tanınmanın da etkisiyle enerjisini iç politikaya yönlendirmiştir. Diş politikada sükûnet dönemi olarak isimlendirilebilecek olan bu dönemde dış politikanın en başta gelen amacı, Lozan'la tesis edilen güvenliği muhafaza etmek ve Türkiye'nin bir "Avrupa gücü olarak kabul edildiğini görmek" olmuştur (2003: 48-50).

Türkiye, Lozan'da çözülemeyen sorunları, pürüzleri "uzlaşma" ile çözme yoluna gitmiştir. Lozan'da çözülemeyen temel sorunların başında ise Musul Meselesi yer almıştır. Lozan görüşmeleri sırasında buhranlı konuların başında olan Musul, Lozan sonrasında Türkiye ile İngiltere arasındaki en önemli siyasi çatışma öznesi haline gelmiştir. 1924 yılında gerçekleşen İstanbul Konferansı'nda bir karar alınamayınca sürece Milletler Cemiyeti dâhil edilmiştir. (Yılmaz, 2017: 431-432). Milletler Cemiyeti'nin kararı sonucunda Musul Meselesi ancak 5 Haziran 1926'da imzalanan ve genel olarak Ankara Antlaşması olarak bilinen antlaşma ile neticelenmiştir (Kurtcephe-Beden, 2008: 458). Türkiye'nin istediği tarzda çözemediği Musul Meselesi'nden sonra Türk dış politikasının temel hedefi Hatay olmuştur (Turan, 1998: 53). Türkiye ile Fransa arasında 20 Ekim 1921'de yapılan Ankara Anlaşması ile Sancak/İskenderun Sancağı Türkiye sınırları dışına kalmıştır. Ankara Anlaşması ile Misak-1 Milli sınırları içerisinde bulunan Hatay'da Türklerin haklarını koruyacak bir dizi imtiyaz elde edilmişse de Türkiye'nin Hatay'a olan ilgisi sürmüştür. 1935 y1lında Fransa'nın Suriye ve Lübnan'daki manda yönetiminin sona ermesi sonrasında 1938'de bağımsızlığına kavuşan Hatay, 1939 yılına geldiğimizde ise Türkiye ile birleşerek anavatana katılmıştır. Hatay'ın ya da 
Sancak'ın Türkiye'ye katılması ile birlikte Türkiye'nin Lozan'dan sonra odaklandığı en önemli sorunlardan bir tanesi daha çözülmüştür (Uçarol, 2000: 589-594).

Bu dönemde Türkiye için oldukça önemli sorunlardan bir diğeri olan Boğazlar Meselesi, Lozan görüşmeleri sırasında üzerinde en çok tartışılan konular arasında olmuştur. Boğazlar konusunun yalnızca Türkiye'yi değil aynı zamanda Sovyet Rusya'yı da ilgilendirmesi, konferans sırasında oldukça yoğun tartışmaların yaşanmasına neden olmuştur (Sonyel, 2003: 311-315). Görüşmeler sonucunda Boğazlarda tesis edilen bağımsız yapı, Türkiye'nin Lozan sonrasında "uzlaşı” yoluyla uzun erimde çözüm sağladığı bir diplomatik başarı olmuştur. İtalya'nın Akdeniz'de, Almanya'nın ise kıta Avrupa'sında meydana getirdiği hareketlilik nedeniyle Türkiye, 1933 yılından itibaren Boğazların statüsü ile ilgili taleplerini gündeme getirmeye başlamıştır. Türkiye'nin çabaları 20 Temmuz 1936'da karşsllk bulmuş, II. Dünya Savaşı öncesinde yaşanan gerilimin etkisiyle Boğazlar için eski rejimi ilga edilip Türkiye'nin egemenliğine imkân tanıyan Montreux Boğazlar Sözleşmesi imzalanmıştır (Akgün, 1994: 220).

Lozan sonrası dönemde takip edilen dış politikada Türkiye, bir taraftan Batı ile ilişkilerini geliştirmeye çalışırken bir diğer taraftan da Milli Mücadele döneminden itibaren destek aldığı Sovyet Rusya'ya yönelik yakın bir politika takip etmiştir. Türkiye, 1925 yılında imzaladığ 1 dostluk anlaşmasıyla Sovyet Rusya ile (Gürün, 2010: 109)1 1932 yılında ise dâhil olduğu Milletler Cemiyeti üyeliğiyle de İngiltere ile ilişkilerini geliştirmeyi sağlamıştır (Uçarol, 2000: 578-579). Türkiye, dünyada revizyonist politika güden ülkelerin sayısının arttığı bir dönemde revizyonist politikaları dünya barışı için tehlikeli görmüştür. Özellikle Almanya ve İtalya başta olmak üzere I. Dünya Savaşı'nın sonuçlarından memnun olmayan pek çok ülkenin ${ }^{2}$ revizyonist politikaları (Armaoğlu, t.y. : 175) karşısında Türkiye, mevcut statükoyu muhafaza etmek üzere 9 Şubat 1934'te Balkanlarda Balkan Antantı'nı; 8 Temmuz 1937'de ise İran, Irak ve Afganistan ile de Sâdâbâd Paktı'nı imzalayarak bölgesel paktların kurulmasına ön ayak olmuştur (Uçarol, 2000: 579-589; Bıyıklı 2008: 340).

Lozan Antlaşması'nın imzalanması sonrasında Türkiye'nin izlediği dış politika iki dönem şeklinde değerlendirilebilmektedir. 1923-1930 yılları arasında Türkiye, ilk olarak Lozan'da halledilemeyen pürüzlerin giderilmesi için yoğun bir dış politika takip etmiştir. İkinci dönem ise dünyanın hızla II. Dünya Savaşı atmosferine girdiği süreci, 1931-1939 yılları arasını kapsamıştır. Bu dönemde Türk dış politikasının odak noktasında, revizyonist devletler -özellikle de İtalya- karşısında bölgesel paktlar kurulması ve anti revizyonist Batılı devletlerle ittifak arayışı içerisine girilmesi yer almıştır (Berber, 2008: 237-246).

\section{Ali Türkgeldi’nin 1935 Yılı Raporu}

Almanya'da Adolf Hitler'in 1933 yılında iktidara gelmesinden sonra, Alman dış politikası ve buna bağlı olarak dünya siyaseti değişime uğramıştır. Hitler, Almanya'yı güçsüz bırakan Versay Antlaşması'nın meydana getirdiği sınırlamaları ortadan kaldırmak isterken bununla birlikte Almanya'nın bir dünya gücü haline gelmesini istemiştir. Hitler için bunu sağlayacak temel rotalardan ikisi aynı zamanda Türkiye'nin de parçası olduğu Balkanlar ve Ortadoğu olmuştur. Almanya'nın dünya politikasında meydana getirdiği değişiklik, Cemil Koçak tarafından 'kesik' olarak nitelendirilen Türk-İngiliz ilişkilerine bir ivme kazandırmıştır. Dünyanın hızla II. Dünya Savaşı’na sürüklendiği dönemde (1933-1939) başlayan İngiliz-Alman nüfuz mücadelesi, Türkiye üzerinde de ciddi biçimde hissedilmiştir (Koçak, 2013: 97-99). Türkiye'nin Alman ve İngiliz nüfuz mücadelesi arasında kalması, Ankara'nın Sovyet Rusya'ya dayanma gerekliliğini ortadan kaldırmıştır. Fakat buna rağmen Türkiye, Sovyet Rusya'dan tamamen de uzaklaşmamıştır. Türkiye'nin İngiltere ve Fransa ile ilişkilerinin gelişmesi için 1936 yılını beklemek gerekmiştir (Armaoğlu, t.y.: 47).

\footnotetext{
${ }^{1}$ Dostluk ve Tarafsızlık Antlaşması (17 Aralık 1925).

${ }^{2}$ Avusturya, Macaristan, Bulgaristan.
} 
Dünyanın savaşa sürüklendiği 1930'lu y1llarda tercih etmemekle birlikte Türkiye, birbirine karşı cephe alan Almanya ve İngiltere'nin rekabetine sahne olmuştur. Bu koşullar altında, savaşın yaşanmadığ 1 bir süreçte Türkiye, iki ülkenin birbirleriyle olan mücadeleleri sebebiyle Boğazlar Sorunu ve Hatay Meselesi konularında istediği çözüme kavuşmuştur. 15 Mart 1939'da Hitler'in ordularının Prag'a girmesiyle birlikte İngiltere için Türkiye'nin önemi daha da artmıştır. Prag işgalinden birkaç hafta sonra İngiliz İmparatorluk Savunma Stratejisi Değerlendirme Alt Komitesi'nde çok gizli kaydıyla hazırlanan raporda Türkiye'ye 'verilmesi gerekenler' saptanmıştır. $\mathrm{Bu}$ dönemde İngilizler, Ankara'nın da telkiniyle Türkiye'deki Alman ve İtalyan propagandasına önemli kozlar vermemek üzere Hatay konusunu, Türkiye için akılcı bir çözüme kavuşturmak üzere Fransa'ya bask1 yapmak zorunda hissetmiştir. Bu zorunluluğun neticesinde 23 Haziran 1939'da imzalanan antlaşma ile Hatay, Türkiye'ye katılmıştır (Akgün, 1994: 220-221).

1935 yılında Batı ile ittifakın henüz sağlanamadığı buna karşın uluslararası ilişkilerde dikkate alınan bir role sahip olmaya başlayan Türkiye'nin, dış politikasına delalet etmek üzere, meydana gelen gelişmeler karşısında Ali Türkgeldi, "Katibi Umumî vekili" sıfatıyla ${ }^{3}$ bir rapor kaleme alarak II. Dünya Savaşı öncesinde dünyadaki gelişmeleri değerlendirmiştir. Her ne kadar rapor Haziran-Temmuz ayı gelişmelerine odaklanmış olsa da raporun yazıldığ 1 tarihe kadar 1935 yılında meydana gelen tüm gelişmeler, bu süreç içerisinde değerlendirmeye alınmıştır. Türkgeldi’nin dış politika raporu daha çok, Avrupa'da ve Avrupa merkezli meydana gelen gelişmelere yer vermiştir. Fransız-İtalyan ve Fransız-İngiliz Anlaşmaları, İngiliz-Alman İhtilafı, Habeşistan Meselesi, Hava Misak1, Şark Misakı, Tuna Misak1, Habsburglar Meselesi, Türkiye ve Balkan Devletleri, Avrupa'da meydana gelen iç politik gelişmeler, Türkiye'nin siyasi ve ticari ilişkileri konularında ele alınan rapor, Türkiye'nin kısa bir süre içerisinde meydana gelen olayları nasıl değerlendirdiğini, analiz ettiğini göstermektedir (BCA, 30-10-0-0 / 219-476-5). Tüm bunlara karşın Türkgeldi raporunda, Türkiye'nin içerisinde bulunduğu şartlar nedeniyle Türkiye ile direkt ilgili olmayan ülke ve gelişmelerle -Çin-Japon savaşı gibi- ilgili bir değerlendirmede bulunmamıştır.

\subsection{Fransız-İtalyan ve Fransız-İngiliz Anlaşmaları}

Ali Türkgeldi, oldukça geniş bir şekilde ele aldığı raporunun başlangıç kısmında, ilk olarak 7 Ocak 1935 Fransız-İtalyan Anlaşması ve 3 Şubat 1935 tarihli Fransız-İngiliz İtilafi ile bu anlaşmaları tamamlamak üzere Fransa, İngiltere ve İtalya başbakan ve dışişleri bakanlarının Stresa'da 14 Nisan 1935 tarihinde gerçekleştirdikleri konferansa yer vermiştir. Rapor, yapılan görüşmelerle bağlantılı olarak 2 Mayıs'ta Fransız-İtalyan; 16 Mayıs'ta ise Rus-Çekoslavak karşılıklı emniyet anlaşmalarının; Hitler'in 13 maddelik bir program-nutkunun ve İtalya-Habeşistan meselesinin Haziran-Temmuz döneminde Avrupa'daki siyasi faaliyetlerin temelini teşkil ettiğini ifade etmiştir (BCA, 30-10-0-0 / 219-476-5: 1).

Türkgeldi’nin raporunda özellikle üzerinde durduğu konu Stresa Konferansı olmuştur. Zira İngiltere, Fransa ve İtalya Stresa'da aynı zamanda, Almanya'nın silahsızlanması konusunu görüşmüşlerdir (Armaoğlu, t.y.: 253). Türkgeldi, raporunda Stresa'da Fransa, İngiltere ve İtalya devletlerinin aralarında "müttehit bir cephe" vücuda getirdiklerini vurgulamıştır. Üçlü arasında özellikle silahlanma konusunun öne çıktığı vurgulanmıştır. Hitler'in açıklamasından ve Alman dışişleri bakanının İngiltere'nin Berlin elçisi ile yaptığı konuşmadan elde edilen bilgiler doğrultusunda nicel bir açılamaya yer veren Türkgeldi, Stresa'da Almanya'nın kara ordusunun 550 bin kişiden müteşekkil olması; hava silahlanmasının Fransa ile eşit şartlarda olması; denizlerdeki durumunun ise İngiliz donanmasının \% 38'i kadar olması gerektiği şeklinde bir düşüncenin ortaya çıktığını ifade etmiştir. Türkgeldi’ye göre üç devletin ittifakına rağmen İngiltere, 18 Haziran 1935

\footnotetext{
${ }^{3}$ Osmanlı Devleti'nde sadaret müsteşarı olarak görev yapmış olan Ali Fuat Bey'in oğlu olan hariciyeci Emin Ali Türkgeldi, 64 yaşındaki iken Tahran Büyükelçisi olarak görev yaptığı İran’da, 1955 yılında vefat etmiştir. Meslek kariyerinde çeşitli görevler üstlenen Emin Ali Türkgeldi’nin "Mudanya Mütarekenamesi Tarihçesi”, "Brezilya”, "Talat Paşa ve Hayatı Siyasiyesi”, “Arnavutluk” gibi eserleri bulunmaktadır, Taha Toros Arşivi, Dosya No: 191.
} 
tarihli Alman-İngiliz Deniz İtilafını imzalamakla, Stresa Cephesine ilk darbeyi vuran devlet olmuştur (CA, 30-10-0-0 / 219-476-5: 1).

\section{2. İngiliz-AIman Deniz Antlaşması}

1935 yılının Haziran ayının başında İngiliz yetkililerle, aralarında Hitler'in oldukça itimat ettiği Joachim Von Ribbentrop'un da bulunduğu Alman yetkililer arasında Londra'da gerçekleşen görüşmelerde beklenilenin üstünde bir gelişme ile iki taraf arasında 18 Haziran 1935 tarihinde bir anlaşma imzalanmıştır. Yapılan antlaşma ile Alman fillosunun İngiliz filosunun \% 35 'ini geçmeyeceği kararına varılmıştır. Bir diğer dikkat çeken madde ise İngiltere'nin getirdiği sınırlama ile denizaltıları kapsam dışında tutması olmuştur. Almanya antlaşma ile İngiliz filosunun genel tonajı oranında denizaltı yapma hakkına sahip olmuştur. Fakat bu oranın \% 45 'i aşmaması kabul edilmiştir. İngilizler, daha fazla denizaltı inşasına zaruret olması halinde ise Almanların haberdar etme ve "dostane" müzakere etme hakkını saklı tuttuklarını kabul etmiştir. Türkgeldi’ye göre İngilizlerin Almanya lehine bu istisnayı kabul etmesi, İngiltere'nin denizaltı sayısının Fransa'nın sahip olduğu denizaltı sayısından aşağıda kalmasından kaynaklanmıştır (CA, 30-10-0-0 / 219-476-5: 1).

Türkgeldi, Almanların yapılan antlaşmayı, Hitler'in bir zaferi olarak gördüklerini kaydetmiştir. Antlaşmayı, Versay'ın silahlanmaya dair olan kararının ilgası olarak kabul eden Almanya için antlaşma, aynı zamanda yeni Avrupa siyasetinin başlangıcı olarak kabul edilmiştir. Yapılan antlaşma ile Almanya ve İngiltere'nin yakınlaşacağ 1 kanaati oluşsa da Türkgeldi, Almanya'da antlaşmaya karşı gün geçtikçe olumsuz bir bakışın ortaya çıktığı bilgisini de vermiştir. Tüm bunlara karşın genel ekseriyetiyle, gerek İngiltere gerekse Almanya yapılan antlaşmadan memnuniyet duymuştur. İngiltere, yapılan antlaşma ile Almanya'nın kontrol altına alındığını düşünmüştür. Anlaşmaya karşı en çok itiraz İtalya ve Fransa'dan gelmiştir. Özellikle Fransa, anlaşmayı en ağır şekilde itham eden ülke olmuştur. Ali Türkgeldi, Fransa'nın tepkisini Türkiye'nin Paris Büyükelçiliğinden aldığı bilgiler doğrultusunda değerlendirmiştir. Antlaşma karşısında "Fransızlar bunu kendilerine inen büyük darbelerden biri" saymıştır (CA, 30-10-0-0 / 219-476-5: 23). Türkgeldi'ye göre Alman-İngiliz Antlaşması Avrupa siyasetinde fiili bir sonuç ortaya çıkartmıştır. Bu doğrultuda Habeş Meselesi ortaya çıktığında İngilizler, İtalya'ya baskı kurmak üzere Fransa'ya müracaat ettiklerinde Fransa, İngiltere yerine İtalya'nın tarafını tutmuştur (CA, 30-10-0-0 / 219-476-5: 5-8).

\subsection{Habeşistan Meselesi}

Ali Türkgeldi’nin hazırladığı raporun bir diğer belki de en önemli konusu İtalya'nın Habeşistan'ı işgali meselesidir. İtalya'nın Habeşistan'a yönelik ilgisi XIX. yüzyılda başlamıştır, fakat İtalya'nın Habeşistan'ı ele geçirmesi; I. Dünya Savaşı, 1929 Ekonomik Buhranı gibi sebeplerle gerçekleşmemiştir. 1931 yılında Japonya'nın Mançurya'yı işgal etmesi, 1925'ten itibaren Habeşistan'la ilgili fırsat bekleyen Mussolini için gereken firsatı sağlamıştır. Milletler Cemiyeti'nin Japonya'ya yaptırımda bulunmaması karşısında ve Almanya'nın faaliyetlerine rağmen bir yaptırıma uğramaması nedeniyle Mussolini, harekete geçmeye karar vermiştir (Armaoğlu, t.y.: 251-253). Türkgeldi'nin işaret ettiği üzere İngiltere ve Almanya'nın anlaşmasının Fransa üzerinde meydana getirdiği tepki, İtalya'nın Habeşistan'ı işgali için istediği fırsatı sağlamıştır (BCA, 30-10-0-0 / 219476-5: 7). Tüm bu gelişmeler üzerine İtalya, Habeşistan'a Ekim 1935 'te saldırmıştır (Uçarol, 2000: 538).

Mussoli'nin Akdeniz çevresi başta olmak üzere gösterdiği yayılma arzusu, Türkiye'yi oldukça tedirgin ve rahatsız etmiştir. Bu çerçevede Mussoli'nin 1934 yılında yaptığı bir açıklamada İtalya'nın Asya ve Afrika'daki emellerini açığa vurması üzerine, Türkiye bu durumu tehlike olarak kabul edip askeri hazırlıklara girişmiştir. İtalya, çok geçmeden Türkiye'ye karşı bir niyet beslemediğini ifade etmişse de ertesi yıl Habeşistan'a saldırması, Ankara için durumun ciddiyetini gözler önüne sermiştir (Soysal, 1999: 293-294). 
Türkgeldi'nin İtalya'nın Habeşistan meselesinin üzerine gittiği bu dönemde, Habeşistan konusuna raporunda ayrı ve de oldukça detaylı bir yer ayırdığı görülmüştür. Türkgeldi, Habeşistan meselesi ile ilgili ilk olarak tarihsel gelişmeleri paylaşmıştır. İtalya, Fransa ve İngiltere'nin Habeşistan üzerindeki tarihsel nüfuz mücadelesine ve bunlarla ilgili olarak yapılan savaş ve anlaşmalara yer veren Türkgeldi, Habeşistan meselesini 1896'dan 1935'e kadar olan dönem olarak ele almıştır. Avrupa'daki dengeyi sürece dâhil ederek konuyu tetkik eden Türkgeldi, Ağustos ayında Habeşistan meselesi konusunda Fransız devlet adamı Pierre Laval ile Cemal Hüsnü'nün ${ }^{4}$ görüşmelerine yer vermiştir. Laval'a göre, tüm diplomatik girişimlere karşın Mussolini Habeşistan meselesi konusunda geri adım atmayacaktır. Türkgeldi'ye göre ise İngilizler açıktan açığa Habeşistan'1 himaye etmektedir. İngiltere'nin Habeşistan'1 İtalya'ya karşı himaye etmesinde, Milletler Cemiyeti'nin mevcudiyetini sürdürmek istemesi zahiri sebepken batıni sebepler ise çok daha farklı olmuştur. Raporda Hindistan yolunun serbestisi, Nil nehrinin kaynaklarının kuvvetli bir devletin eline geçmemesinin gerekliliği, Afrika'yı kuzeyden güneye geçen Kahire-Kap hattında Londra'nın yetkin olması gibi sebepler; İngiltere'nin Habeşistan'ı desteklemesinin batıni nedenleri olmuştur. Türkgeldi'ye göre İngiltere aynı zamanda dahili ve harici prestij için Habeşistan meselesi ile ilgilenmektedir. Buna göre İngiltere, küçük bir devleti işgalden kurtararak Avrupa kamuoyunda, Milletler Cemiyeti'nde ve diğer mahfillerde "büyük bir şan ve şeref” kazanacaktır. Ayrıca Türkgeldi, İtalya'nın yenilmesinin veya galip gelmesinin İngiltere'nin kendisinin de sömürgesi altında bulunan “Afrikadaki zenci milletleri öfkelendir"mesinden ve sömürgelerin kendilerine karşı ayaklanıp isyan etmesinden çekinmiştir (BCA, 30-10-0-0 / 219-476-5: 8-15).

İngiltere dışındaki devletlerin Habeşistan konusundaki tavrı ise daha farklı olmuştur. Fransa'da İtalya-Habeşistan melesinde hâkim olan fikir, "İtalyanlara temayül ile beraber Cemiyeti Akvamın nüfuzunu muhafazaya gayret etmek şeklindedir.” Fransa'nın esas endişesi, İtalya'nın Habeşistanlıların mücadeleci yapısı sebebiyle alışık olmadıkları bir iklimde uzun bir müddet mücadeleye mecbur kalarak -Avusturya'da- Almanlara karşı savunma mecburiyetinde kaldıklarında, ellerinde yeterli derecede kuvvet bulunamayacak olmasıdır. Rapordan ortaya çıtı̆̆ı kadarıyla Fransa için esas sorun Habeşistan'ın işgali değil işgal esnasında İtalya'nın güç kaybederek Avrupa'da Almanlara karşı mücadelede zafiyet göstereceğidir. Bu sebeple Fransa Cumhurbaşkanı Türkiye'nin Paris Büyükelçisine Mussoli'nin Habeşistan siyasetini beğenmediğini ve İtalya kamuoyunda da memnuniyetsizlik olduğunu gizli bir şekilde ifade etmiştir. Almanya ise Habeş meselesine dâhil olmadığını ve Habeşistan'a silah vermeyeceğini Roma elçisi vasıtasıyla bildirmiştir. Türkgeldi, Berlin ve Belgrad Elçiliklerinden gelen raporlar doğrultusunda Almanya'nın tutumunun tutarlı olduğunu ifade etmiştir. Türkgeldi'nin raporunda Çekoslovakya Cumhurbaşkanı Edvard Beneş'in Türkiye'nin Prag maslahatgüzarına söylediği “Almanya, İtalya'yı Habeş işinde istediği gibi harekete teşvik etmektedir” sözleri, Almanya'nın İtalya'yı yanına çekmek istediğini ortaya koymaktadır. Keza raporda Habeş konusunda görüşüne önem verilen bir devlet ise ABD olmuştur. Türkiye'nin yakın ilişkiler kurduğu bir devlet olmamasına rağmen yine de ABD'nin görüşlerine yer verilmiştir. Resmi açıklamalarında $\mathrm{ABD}$, sürecin Milletler Cemiyeti içerisinde çözülmesinden yana olduğunu ifade etmiştir. Türkiye'nin Washington Büyükelçiliğinin değerlendirmelerinden vardığı sonuçta ise Türkgeldi, ABD'nin İtalya-Habeşistan meselesine dâhil olmak istemediği gibi muhtemel İtalyanHabeş savaşına karışmaktan da çekindiği tespitinde bulunmuştur. Büyükelçilikten alınan 6 Temmuz tarihli raporda, ABD'nin Çin-Japon ve Rusya-Çin ihtilaflarında faal bir rol oynamakla birlikte Habeş meselesi ile alakalı olmamasından dolayı ilgilenmediğine yer verilmiştir. Buna karşın İtalya'nın eylemlerinin ABD'de olumlu bir destek görmediği de husussan belirtilmiştir. Rusya’nın görüşünü Bern Büyükelçiliği vasıtasıyla raporuna ekleyen Türkgeldi, Rusya'nın Habeş meselesindeki rolüne çok az yer ayırmıştır. Maksim Litvinov'un sözlerine yer verilen raporda, Sovyet Rusya'nın

\footnotetext{
${ }^{4}$ Cemal Hüsnü Taray, 31 Ekim 1930-19 Ağustos 1936 tarihleri arasında Türkiye'nin Bern Büyükelçisi olarak görev yapmıştır; Bknz., Hariciye Vekâleti Yıllığı 1959, s. 12; Muzaffer Başkaya, "Atatürk’ün Genç Diplomatı ve Türkiye'nin Milletler Cemiyeti'ndeki İlk Daimî Temsilcisi: Cemal Hüsnü Taray'ın Hayatı ve Diplomatik Faaliyetleri", Tarih Okulu Dergisi, XXXIV, Haziran 2018, s.667-685.
} 
diplomatik bir tutum içerisinde olduğu görülmüştür. Türkgeldi'ye göre Japonya kamuoyu ise Habeşistan'ın lehindedir, keza hükümette bu durumdadır. Japonya'nın resmi ve kamuoyu tutumu, İtalya basınında Japonya aleyhinde bir tutum takınılmasına yol açmıştır (BCA, 30-10-0-0 / 219-4765: 15-18).

İtalya-Habeşistan meselesindeki tüm değerlendirmelerden sonra bir sonuç yazma ihtiyacı hisseden Türkgeldi, İtalya'nın hazırlıklarının muazzam bir devletle savaşa hazırlanmalarını andırdığı değerlendirmesinde bulunmuştur. Türkgeldi, konuyla ilgilenen tüm devletlerin değerlendirmeleri ışı̆̆ında savaşın kaçınılmaz olduğunu yazmıştır. İngiltere'nin Habeşistan'a sağladığı destek sebebiyle İtalyanların kolay bir zafer elde edemeyeceğini düşünen Türkgeldi, aynı zamanda coğrafi yapının zorluğu sebebiyle de İtalya'nın kazanmasının zor olacağını ifade etmiştir. Savaşın uzaması halinde ise bütçesi sarsılacak olan İtalya'nın dış ilişkilerinin zarar göreceği değerlendirmesinde bulunulmuştur. Türkgeldi, İtalya'nın içine düştüğü durumdan istifade edecek ülkenin ise Almanya olacağı öngörüsünde bulunmuştur. Raporda savaşın uzaması halinde İtalya'nın Yugoslavya ve Türkiye'ye yöneleceğinin beklenebileceği de ayrıca ifade edilmiştir. Savaş nedeniyle zayıflayan İtalya'nın Akdeniz ve Balkanlar'da Türkiye ve Yugoslavya ile karşı karşıya gelmek yerine bu ülkelere dostça yaklaşması beklenen bir adım olarak düşünülmüştür. Habeş ihtilafında diğer seçeneği değerlendiren Türkgeldi, İtalya'nın galip gelmesi halinde, İngiltere'nin Sudan, Hint Yolu ve İngiliz Somali'si konularında bir tehlike yaşayacağını bu durumun ise İtalya-İngiliz ilişkilerinin bozulmasına yol açacağı ve İtalya-İngiliz çatışmasının Fransa'yı zor bir durumda bırakacağı öngörüsünde bulunmuştur. Türkgeldi'nin 1935 y1lı sona ermeden kaleme aldığı raporun İtalya-Habeş meselesine bakışı, Türkiye açısından tek bir kelimede adeta vücut bulmuştur. İtalya'nın Habeşistan eylemi için "sergüzeşt" ifadesini kullanan Türkgeldi, Türk dış politikası açısından İtalya'nın içine atıldığı süreci bir macera, serüven olarak değerlendirildiği anlaşılmaktadır (BCA, 30-10-0-0 / 219476-5: 19-21).

\subsection{Hava Misakı}

1935 y1lı raporu için Habeşistan meselesi oldukça önemli bir yekûn tutmuştur. Habeşistan meselesi dışında Ali Türkgeldi'nin yer verdiği diğer bir konu ise Hava Misakı olmuştur. 3 Şubat 1935 tarihli Londra beyannamesinde, olası bir mahalli hava taarruzunda İngiltere ve Fransa, zarara uğrayacak tarafa yardım etmeyi taahhüt etmişlerdir. Bu hususta Fransa ve İngiltere; İtalya, Almanya ve Belçika'yı bir anlaşma yapma imkânını görüşmek üzere davet etmiştir. Almanya, teklife verdiği cevapta, barışı bozanlara karşı kendi hava kuvvetlerini hazır bulundurmayı esas tuttuğunu ifade ederken birçok devletin iştirakiyle başlayan pek çok müzakerelerin sonunda netice alınamadığını kaydetmiş̧ir. Almanya, ayrıca konunun ilgili devletlerarasında hususi müzakerelerle halledilmesini teklif etmiştir. 14 Nisan 1935 tarihinde Stresa'da, Londra beyannamesi çerçevesinde (3 Şubat 1935) İngiltere, Fransa, İtalya hava misakı hususunda Londra'da kararlaştırılan esasları teyit ederek beş devlet (Fransa, İngiltere, Almanya, İtalya, Belçika) arasında bir anlaşma hazırlanması hususunda karara varmıştır (BCA, 30-10-0-0 / 219-476-5: 21).

Türkgeldi'ye göre silahlanma meselesinde Almanya'nın kara ordusunun nicelik olarak kuvvetlenmesi, en çok Fransa'yı endişelendirmiştir. Almanların deniz ve hava kuvvetlerinin artması ise İngilizleri ürkütmüştür. Türkgeldi’ye göre Alman deniz ve hava kuvvetlerinin artmasında İngilizlerin telaş göstermesi anlaşılır bir durumdur. Zira Türkgeldi, İngiltere'nin sahip olduğu donanma sayesinde karadan gelecek bir saldırıdan endişe etmediğini, fakat Almanya'nın sahip olduğu uçakların sayıca İngilizlere yaklaşmasının İngilizleri düşündürdüğünü ifade etmiştir. İngiltere'nin endişesi, yaşanacak bir Alman saldırısı karşısında Fransa ve Belçika yardımını aramaya mecbur etmiştir. Fakat İngiltere aynı zamanda Almanya'yı da anlaşmaya dâhil ederek Alman hava silahlanmasını sınırlandırmak istemiştir. İngiltere, bu doğrultuda 1935 yılında yoğun bir faaliyete girişmiştir. Bu konuda Almanya'nın görüşü ise Türkiye'nin Berlin Büyükelçiliğinin 14 Haziran tarihli raporunda, Almanya'nın da 'Hava Locarno'su olarak belirtilen girişime yakın olduğu şeklinde 
yer almıştır. Almanya'nın savaş sırasında özellikle sivillerin bulunduğu yerlerin bombardımandan masun tutulmasını istemesi, İngiltere'de oldukça olumlu izlenim bırakmıştır. Fakat tüm bu girişimlere rağmen raporun yazıldığı tarihte istenilen türde bir anlaşma gerçekleştirilememiştir (BCA, 30-10-0-0 / 219-476-5: 21-24).

\section{5. Şark Misakı}

Fransa ile Rusya arasında 29 Kasım 1932 tarihinde imzalanan "ademi tecavüz ve telifi beyn muahedesinden" sonra Fransa tarafından Rusya, Almanya, Çekoslovakya, Polonya ile Baltık devletleri arasında bir "Emniyet Misakı akdi" ve bir de Rusya, Almanya ve Fransa arasında bir "Emniyet Muahedesi” fikri gündeme getirilmiştir (BCA, 30-10-0-0 / 219-476-5: 24). I. Dünya Savaş1 sonunda yapılan antlaşmalarla Avrupa'da, savaşın kazananlarının istedikleri tarzda bir statünün kurulması sağlanmıştır. Her ne kadar bir düzen kurulmuş olsa da I. Dünya Savaşı'nın bitiren barış antlaşmaları, uluslararası birçok sorunu da beraberinde getirmiştir. Bunun sonucu olarak barışın ilk yıllarından itibaren sürekliliği sağlamak üzere çeşitli önlemler alınmak istenmiştir. Bu konuda öne çıkan ülke ise Fransa olmuştur. Fransa, Almanya'nın kendisini sınırlandıran 1919 tarihli Versay Antlaşması'nın hükümlerinden kurtulmak isterken kayıplarını, Fransa'dan tazmin edeceği endişesinden hareketle, Almanya'ya karşı ittifaklar sistemi kurmaya girişmiştir (Uçarol, 2000: 523).

Hitler' in iktidara gelmesinden sonra, Fransa'nın çalışmaları daha da artmıştır. Bu eksende Fransa'nın Almanya'yı sınırlandırmak üzere giriştiği 'Şark Misakı' girişimi, Hitler'in girişimleri nedeniyle akamete uğramıştır. Almanya, Sovyet Rusya' ya karşı baş gösteren ve gittikçe kuvvetlenen görüş karşısında, Şark Misakı gibi kapsamlı bir anlaşmanın imzalanmasına engel olmuştur. Misakın diğer bir muhatabı olan Polonya ise Almanya ile 26 Ocak 1934'te on sene müddetle bir "ademi tecavüz beyannamesi" imzalamıştır. Ali Türkgeldi'ye göre, bu antlaşmanın imzalanmasından sonra Polonyalı yetkililer, Almanya-Polonya ilişkilerinin "dostane" bir şekle girmesi üzerine, Almanya'y1 gücendirmemek ve bir savaş halinde ülkelerini savaş sahasına çevirmemek için antlaşmanın akdine rıza göstermemişlerdir. Fransa ve Rusya'nın aralarında bir emniyet anlaşması yapmasını arzu etmeyen İngiltere, bu doğrultuda Stresa görüşmeleri esnasında Almanya'yı teşvik ederek, Almanya'nın bir saldırmazlık anlaşması akdedeceğini bildirmesini sağlamıştır. Fakat bu girişime rağmen Stresa'y1 müteakip Fransa ile Rusya arasında 2 Mayıs 1935 tarihinde Paris'te “emniyet misakı" imzalanmıştır. 16 Mayıs'ta ise bu kez Rusya ile Çekoslovakya arasında bir emniyet misakı imzalanmıştır. 2 Mayıs tarihli antlaşmaya bağlı protokolün dördüncü maddesinde Almanya'yla anlaşmak ve antlaşmaya dâhil etmek üzere bir "açık kapı" bırakılmıştır. Almanya, yapılan antlaşmanın Locarno Paktı'na "taaruz eyleğinden" hareketle, Haziran ayında Fransa'ya muhtıra vermiş, Locarno'nun imzacı devletlerine ise şikâyette bulunmuştur. Türkgeldi'ye göre, Fransa, Almanya'nın Kuzey Avrupa devletleri ile "ademi tecavüz muahedeleri" akdettikten sonra Hava Misakına taraf olacaktır; İngiltere ise Hava Misakı'nı öncelik olarak ileri sürmektedir. Türk dış politikasının konuya, Sovyet Rusya nazarıyla baktığı görülmüştür. Türkiye'nin Moskova Büyükelçisi aracılığıyla, Rusya'nın Türkiye'nin pakta girmesi konusundaki tutumu öğrenilmiştir. Moskova büyükelçiliğinin raporuna göre Litvinov, Romanya pakta girerse Türkiye'nin de pakta girmesi için çalışacağını ifade etmiş; fakat ne Romanya'nın ne de Çekoslovakya'nın pakta girmesini Almanya'nın uygun bulmadığını ifade etmiştir (BCA, 30-10-0-0 / 219-476-5: 24-27).

\subsection{Tuna Misakı ve Habsburglar Meselesi}

1935 yılı raporunda dikkat çeken diğer bir konu ise Tuna Misakı ile Habsburg Hanedanı meseleleri olmuştur. Avusturya'nın komşuları olan İtalya, Almanya, Macaristan, Çekoslovakya, Yugoslavya gibi devletler aralarında birbirinin siyasi, mülki ve sosyal meselelerine müdahalede bulunmayacaklarına dair 'Tuna Misakı' adıyla bir anlaşma yapmak istemişledir. Mezkûr devletler Tuna Misakı'na aynı zamanda Fransa, Polonya ve Romanya'nın da dâhil olması istemiştir. Diğer taraftan Avusturya'nın siyasi sınırlarının tamamı ve bağımsızlı̆̆ı tehlike altına girdiği zaman, Fransa ve İtalya böyle bir antlaşmanın yapılmasını beklemeksizin birbirlerine ve alınacak tedbirler 
hususunda Avusturya'ya müracaat etmeyi ve aynı zamanda bu müracaatı diğer devletlere teşmil etmeyi kararlaştırmışlardır. İngiltere, Şubat 1935 'te yapılan Fransız-İngiliz anlaşması gereğince İngiltere'nin, Avusturya'nın bağımsızlı̆g tehlikeye girdiği zaman müracaat edilecek devletlerden olduğunu ilan etmiştir (BCA, 30-10-0-0 / 219-476-5: 27).

Türkgeldi’nin raporunda Tuna Misakı'nın üzerinde durma sebebi, konunun Almanya ile ilintili olmasından kaynaklanmıştır. Bu hususta Türkgeldi, Berlin ve Belgrad Elçiliklerinden gelen raporlar 1şığında, İtalya ve Almanya'nın birbiri aleyhinde yayın yapmamayı taahhüt ettiklerini ve Avusturya konusunda gizli tutulan bir anlaşmayla uzlaştıklarını ifade etmiştir. İtalya, Almanya ile yapılan anlaşma sonrasında Tuna Misakı'nın gerçekleşmesine İtalya'nın taraftar olduğunu; fakat Türkiye, Yunanistan ve Romanya'nın sebep olduğu sıkıntılardan dolayı misakın gerçekleşemediğini iddia etmiştir. İtalyan yetkili Suviç, üç devletin de Avusturya'nın bağımsızlığı için taahhüt altına girmek istemediklerini ifade etmiştir. Avrupa devletlerinin Tuna Misakı'na yoğunlaştıkları esnada Almanya karşı hamle yaparak, Avusturya'ya on yıllık bir anlaşma teklif etmiştir. Türkgeldi, Viyana Büyükelçiliğinden gelen rapor doğrultusunda Almanya'nın Viyana elçisi Franz von Papen'in girişimleri neticesinde, Avusturya'nın Tuna Misakı'ndan ümidini kestiğini ifade etmiştir. Keza Almanya'nın teklifi karşısında Beneş, Türkiye'nin Prag Büyükelçisine Avusturya'nın anlaşmayı imzalaması halinde, Alman nüfuzu altına gireceğini söylemiştir (BCA, 30-10-0-0 / 219-476-5: 28$30)$.

Avusturya ile ilgili olan bir diğer önemli konu ise Habsburg Hanedanı meselesi olmuştur. I. Dünya Savaşı'nın sonunda yapılan antlaşmalar neticesinde, Avrupa'nın siyasi haritasında önemli bir yekûn teşkil eden imparatorluklar sona ermiş; Osmanl1, Alman, Avusturya-Macaristan devletleri yıkılmıştır. 1918 yılının Ekim ayında Avusturya-Macaristan İmparatorluğu içerisinde yaşayan Çekler, Macarlar, Hırvatlar, Sırplar, Slovenler sırasıyla imparatorluktan ayrılarak bağımsızlıklarını ilan etmişlerdir. İmparatorluğun sınırlarında kalan son millet ise Avusturya Almanları olmuştur. Avusturya Almanları da 30 Ekim 1918 tarihinde Avusturya Cumhuriyeti'ni ilan etmiştir (Uçarol, 2000: 509 ve 523). 1935 yılına gelindiğinde Avusturya'da Habsburg Hanedanının Avusturya'da ikamet hakkına sahip olması ve mallarının iadesine dair bir kanun yayınlanmışırı. Türkiye'nin dış temsilcilikleri ve büyükelçilikleri aracıllğıyla konuyla alakadar olduğu görülmüş, fakat bu ilgi yalnızca Avrupa'da Tuna Misakı konusuyla sınırlı kalmıştır. Gerek Türkgeldi'nin ifadesi gerekse Avrupa'dan gelen değerlendirmeler, Habsburg ve Osmanlı Hanedanları arasında illiyet ve bă kurulmadığını göstermektedir. Habsburglarla ilgili kanunun yürürlüğe girmesi, "Küçük İtilâf Devletleri" denilen ülkeler nezdinde de olumsuz bir tesir meydana getirmiştir. Romanya, Çekoslovakya gibi devletler kanunun yürürlüğe girmesine yoğun tepki göstermişler hatta Çekoslovakya'nın ağır tepkilerine raporda yer verilmiştir. Romanya ve Çekoslovakya dışında Sırbistan da konuya eleştirel bakmıştır. Roma Büyükelçisinin değerlendirmesine raporunda yer veren Türkgeldi, İtalya'nın Habsburg kararını Avusturya'nın Almanya ile birleşmesini engelleyici son girişim olarak kabul ettiğini yazmıştır. Elçilik, Fransa'nın karara muhalefet etmeyeceğini söylerken İtalya'nın ise kararı desteklediği bilgisini paylaşmıştır (BCA, 30-10-0-0 / 219-476-5: 31-32).

\subsection{Balkan Devletleri ve Türkiye}

1935 yılına ait raporda, bazı başlıkların dolaylı bazı başlıkların ise doğrudan Türkiye ile ilgili olduğu görülmüştür. Bu başlıklar dolaylı ya da doğrudan dahi olsa Türkiye'nin Avrupa'da meydana gelen Almanya merkezli değişimi yakından takip etmesinden ileri gelmiştir. Türkgeldi, Haziran ve Temmuz ayları zarfinda Balkan ülkelerinde meydana gelen gelişmeleri yine bu çerçevede iki kısımda değerlendirmiştir; Balkanlarda meydana gelen olaylar ve Türkiye'nin Balkan devletleri ile olan ilişkileri. Balkan ülkelerinde meydana gelen olaylar ise iki aylık süre zarfında dört konu başlığı altında değerlendirilmiştir. İlk olarak Yugoslavya-Bulgaristan ilişkilerini ele alan rapor, her iki ülkenin yakınlaşmasını tedirginlik içerisinde değerlendirmiştir. Yugoslavya'nın 1934 yılında imzalanan Balkan Antantı üyelerinden birisi olması, Bulgar-Yugoslav yakınlaşmasının Türkiye- 
Yugoslavya ilişkilerine zarar verip vermeyeceğinin elçiliklerden alınan bilgiler 1şı̆̆ında değerlendirilmesine yol açmıştır (BCA, 30-10-0-0 / 219-476-5: 33-35).

İkinci başlık Arnavutluk'un Balkan Antantı'na girmek istemesi ile ilgili olmuştur. İtalya ile Arnavutluk arasında gerçekleştirilen borç görüşmelerinin neticesiz kalması üzerine, Arnavutluk yetkilileri, yaşadıkları ekonomik sıkıntılar nedeniyle alternatif çareler aramaya başlamıştır. İtalya'nın Habeşistan Meselesi ile ilgili olması sebebiyle, Arnavutluk, Yugoslavya vasıtasıyla Balkan ittifakına girmek için teşebbüste bulunmuştur. Türkgeldi, Tiran Elçiliği vasıtasıyla edindiği bilgide Arnavutluk'un İtalya ile bozulan ilişkileri sebebiyle diş politikada, Avrupalı büyük devletler yerine "balkanik" bir tutum içerisine girdiği bilgisini paylaşmıştır. Türkgeldi, raporunda Arnavutluk konusu ile ilgili iki noktayı öne çıkarmıştır. İlk olarak Türkiye'nin Tiran Elçisinin Kral Zogo'yu ziyaretinde Arnavutluk'un niyetleri ile ilgili bir şeyden bahsetmemesini vurgulayan rapor, ikinci olarak ise Arnavutluk'un Türkiye yerine Yugoslavya'ya yönelmesini ele almıştır. Balkan meselesinde ele alınan üçüncü konu ise Yugoslavya'nın dış siyaseti olmuştur. Yugoslavya'da kabine içerisinde yaşanan değişikliğin Türkiye-Yugoslavya ilişkilerine tesir edip etmeyeceği değerlendirilmiştir. Ele alınan dördüncü konu ise, Yunanistan savunma bakanı ve başbakan yardımcısı, Kondilis'in Roma seyahati olmuştur. Kondilis, ziyareti sırasında "Roma'da İtalyan ordusuna, faşizme, Mussolini'ye karş1 hayranlık gösterdiği” ifade edilmiştir. Roma'dan ayrılmadan önce yaptığ1 son ziyarette, Mussolini, Kondilis'e İtalya'nın Yugoslavya ile dost olmak arzusunda olduğunu Belgrad'da anlatmasını istemiştir. Kondilis'in ise Mussoli'nin istediği şekilde yardım ettiği görülmüştür. Türkgeldi'ye göre, Mussoli'nin Kondilis'i bu kadar yüceltilmesindeki maksat, İtalya'nın "Venizelos'un şahsında kaybettikleri İtalyan dostluğuna mukabil" Yunanistan'da yeni ve kuvvetli bir taraftar kazanmak olarak yorumlanmalıdır (BCA, 30-10-0-0 / 219-476-5: 35-40).

Balkan devletleri ile ilgili olarak raporun ele aldığı ikinci ana konu ise Türkiye'nin Balkan devletleri ile olan münasebeti olmuştur. Türkiye için batı sınırlarının güvenliğinin sağlanması demek olan Balkan Antant1, Avrupa'da yaşanan gelişmelere paralel olarak en çok merak edilen konuların başında gelmiştir. Rapor, Balkan Antantı üyesi ülkelerin Türkiye'ye ve Antant'a bakışlarında bir değişiklik olup olmadığını değerlendirmiştir. Bu doğrultuda Yugoslavya Dışişleri Bakanın "Balkan Misakının temelleri Türkiye ve Yugoslavya'dır" sözlerine yer vermiştir. Yunanistan'ın durumunu da değerlendiren rapor, Türkiye'nin "Mart İhtilâli" esnasında Yunan Hükümetine yaptığı yardımların semereleri neticesinde, Atina'nın Türkiye'ye dostluk gösterdiğini kaydetmiştir. Bu doğrultuda Yunanistan Cumhurbaşkanı ve Dışişleri Bakanının Türkiye'ye yönelik dostane sözlerine yer veren rapor, Yunan Dışişleri Bakanı Maksimos'un Türkiye için oldukça dikkat çekici bir gelişme olan General Kondilis'in Roma seyahati ile ilgili olarak Türkiye'nin kaygılarını gidermek üzere yaptığı açıklamalara yer vermiş̧ir (BCA, 30-10-0-0 / 219-476-5: 40-42).

Türkiye'nin 1935 y1lında Balkanlarda tehlike olarak gördüğ̈̈ tek husus Bulgaristan'ın politikaları olmuştur. Bulgaristan, bu dönemde Türkiye karşı1tı bir görüş içerisinde olmuştur. Bulgarlar, Türkiye aleyhinde bir harekette bulunmak üzere, Varna'da tarihi karakter olan Kral Ladislas'ın anıtını açmıştır. Macar Kralı olan Ladislas, Varna'da II. Mehmet tahta ilk kez çıktığında Osmanlıları, Balkanlardan ve Trakya'dan atmak üzere bir Haçlı seferi düzenlemiş ve tarihe Varna Savaş1 olarak geçen savaşta yenilerek ölmüştür (Emecen, 2012: 527-530). Bulgar yetkililerin gerçekleştirdiği Ladislas Anıtının açılışı için resmi olarak davet edilen Yugoslavya, Çekoslovakya ve Romanya hükümetleri açılışa, Türkiye'ye karşı bir iyi niyet göstergesi olarak katılmamışlardır. Ladislas Anıtı örneğinde olduğu gibi Bulgaristan-Türkiye ilişkilerinin 1935 yılı için iyi olmadığı açıktır. Türkgeldi, anıt açılışını tarihi bir vakıa olarak değerlendirip fazla önem vermezken, meseleyi Balkan ve Küçük İtilaf Devletleri'nin Türkiye hakkındaki dostluklarını ortaya koyan bir hadise olarak değerlendirmiştir. Türkiye-Bulgaristan ilişkilerinin arzu edilen şekilde olmadığını ifade eden Türkgeldi, Bulgarların Sırbistan ile dostluk tesis ederek Türkiye ve Yunanistan'a karşı hasmane bir tavır takındığını yazmıştır. Türkgeldi'ye göre her ne kadar Bulgaristan başbakanı ve dışişleri bakanı aksi söylemlerde bulunsa da değişen bir şey yoktur. Türkgeldi, ayrıca Bulgaristan'da Türk azınlığa 
karşı yapılan muamelenin bu durumu gösteren bir delil olduğunu savunmuştur (BCA, 30-10-0-0 / 219-476-5: 42-43).

\subsection{Avrupa'da Meydana Gelen İç Politik Gelişmeler}

Türk dış politikası açısından takip edilen konular, yalnızca devletlerin dış politikada attıkları adımlar olmamıştır. Raporda aynı zamanda devletlerin dış politikalarını da etkileyen iç politik kararlar ve yaşanan değişiklikler yakından değerlendirilmiştir. Bu doğrultuda Türk Büyükelçileri yoğun bir mesai harcamışlardır. Fransa, İngiltere, Yunanistan ve Yugoslavya'da Haziran ve Temmuz aylarında yaşanan kabine değişiklikleri, ilgili devletlerin değerlendirilmeye alınmalarının sebebini oluşturmuş̧ur. Raporda kabinelerin değişme sebebinden başlayarak ilgili devletin içyapısının en ince ayrıntısına kadar ele alındığı görülmüştür. Raporda aynı zamanda yaşanan kabine değişikliklerinin Türkiye ile ilişkilere ne ölçüde etki edeceği mümkün mertebe elçiler tarafindan merkeze bildirilmiştir (BCA, 30-10-0-0 / 219-476-5: 44-52).

\subsection{Türkiye'nin Siyasi ve Ticari İlişkileri}

Ali Türkgeldi'nin kaleme aldığı raporda, Türk dış politikası açısından ele alınan bir diğer konu ise Türkiye'nin kurduğu siyasi ve ticari ilişkiler olmuştur. Raporda değerlendirmeye tabi k1lınan ilk devlet ise İran olmuştur. İran Şahı'nın bir önceki yıl gerçekleşen Türkiye ziyareti ve Türkiye-İran dostluğu, İran başlığının eksenini oluşturmuştur. Şah'ın Türkiye ziyareti sonrası aldığı ilham neticesi olarak şapka, tesettür konularında kararlar alması ve Türkiye-İran arasındaki sınır sorunun büyük bir oranda çözülmüș olması, ikili ilișkilerin başarılı bulunduğuna ișaret olarak kabul edilmiştir. Ele alınan ikinci devlet ise Afganistan olmuştur. İran ile Afganistan arasındaki sınır sorunlarından bahseden rapor, Türkiye'nin sınır sorunlarını çözmek üzere devreye girerek Fahrettin Altay'ı görevlendirdiğinden bahsetmiştir. Afganistan Dışişleri Bakanı tarafından yayınlanan tebliğde Türkiye'den, soruna sağladığı katkıdan ve Fahrettin Altay'ın çalışmalarından sitayişle bahsedilmiştir. Türkiye, 1935 yılında ileride Sâdâbâd Paktı'nın üyesi olacak iki ülkenin arasındaki sınır sorunlarının çözümüne katkı sağlayarak, II. Dünya Savaş1 öncesi tıpkı Balkanlarda olduğu gibi doğuda da bir ittifak vücuda getirmiştir. Sâdâbâd Paktı'nın 1937 yılındaki kurucularında olacak olan Irak, 1935 yılındaki raporda ele alınan bir diğer devlet olmuştur. Irak başlığında da sınır sorunu ele alınmış ve İran-Irak sınır sorunlarından bahsedilmiştir. Türkiye'nin sınır sorununu yabancı ülkeleri sürece dâhil etmeden İran ve Irak hükümetleri arasında halledilmesi tavsiyesinin iki ülke tarafindan müspet karşılandığı raporda yer verilen husus olmuştur (BCA, 30-10-0-0 / 219-476-5: 53-54).

Raporun İran, Afganistan ve Irak dışında harici bir başlık açtığı devlet ise Rusya olmuştur. Rusya ile Türkiye arasındaki ilişkilerin önemli olduğu bu dönemde Litvinov, Milletler Cemiyeti'nin Mayıs toplantısında Tevfik Rüştü Aras'a Türkiye ile "mevcuttan ileri bir şey yapmayı düşündüm, doğrusu bulamadım. Çünkü biz Almanlardan gayri herhangi bir ddevlete müteveccih bir taahhüde girişmek istemiyoruz" demiştir. Aras ise Litvinov'a hak vererek mevcut "Şark Paktı" ile ilgili bir teşebbüse girişilebileceğini teklif etmiş, Litvinov ise bunu müspet bulmuştur. Ancak iki tarafin isteğine rağmen yine de istenilen tarzda bir girişim sağlanamamıştır. Fakat İktisat Vekili Celal Bayar'ın gerçekleştirdiği Moskova seyahati esnasında Bayar, Türk-Sovyet dostluğunu oldukça samimi bulduğunu ifade etmiştir (BCA, 30-10-0-0 / 219-476-5: 55-61).

Türkiye, doğu ve kuzey komşuları ile ilişkilerini geliştirirken aynı zamanda batı ile münasebetlerini ilerletmek yoluna gitmiştir. Bu doğrultuda 4 Haziran 1935 tarihinde Ankara'da İngiltere ve Türkiye arasında yeni bir ticaret anlaşması imzalanmıştır. Aynı dönemde İspanya, Finlandiya, Bulgaristan ve Romanya ile de ticaret anlaşmaları ya da mevcut antlaşmaların tadili yapılmıştır. Fakat İngiltere'yi diğer ülkelerden ayıran temel fark, tıpkı 1 Mart 1930 tarihli Ticaret Muahedenamesi'inde olduğu gibi İngiltere'nin yine "en ziyade müsaadeye mazhar millet" olarak kabul edilmesi olmuştur. Bu durum Avrupa'da kamplaşmaların yaşandığı bir dönemde Türkiye'nin Rusya'ya rağmen İngiltere'ye doğru yöneldiğini göstermektedir (BCA, 30-10-0-0 / 219-476-5: 55$61)$. 


\section{Numan Menemencioğlu'nun Değerlendirmesi}

"Hariciye Vekâleti Kâtibi Umumisi” Numan Menemencioğlu ${ }^{5}$ kendisinden bağımsız olarak kaleme alınan Ali Türkgeldi'nin raporunu, rapor yazıldıktan sonra değerlendirmiştir. Menemencioğlu, özü itibariyle raporu analiz ederken raporda tahlil edilip eklenecek bir şey göremediğini ifade etmiştir. Ancak rapora haşiye olmak üzere arz etmek istediği birkaç nokta olduğunu da kaydetmiştir. Menemencioğlu, arz etmek istediği noktaların Türk dış politikasının takip etmekte olduğu ve gelecek aylarda daha da yakından takip etmesi gerekecek vaziyetlerin şematik bir ifadesi olduğunu ifade etmiştir. Haşiye olarak yedi nokta öne çıkartılmıştır. Menemencioğlu, ilk olarak Sovyet Rusya'nın batılı devletlerle tesis ettiği yakınlaşmanın yalnızca "Almanya'ya karşı" olan bakış açısından değil aynı zamanda "Bahri Sefit müvazenesi noktasından" da dikkatlice takip edilmesi gerektiğini ifade etmiştir. Menemencioğlu, Rusya'nın Fransa ve İtalya ile ayrı yaptığı anlaşmaları, Sovyet Rusya'nın pasif politikadan aktif politikaya geçişi için bir aşama olarak görmüştür. $\mathrm{Bu}$ sebeple Menemencioğlu, Türkiye'nin 'büyük komşusu' ile ilişkisi sebebiyle gelişmelerin çok yakından ve ilgi ile takip edileceğini ifade etmiştir (BCA, 30-10-0-0 / 219-476-5: $1)$.

Menemencioğlu'nun dikkat çektiği ikinci konu ise İtalya-Habeş meselesi olmuştur. Menemencioğlu'na göre, Habeşistan Meselesi, bölgesel bir konu olmaktan daha çok, Avrupai bir meseledir. Habeşistan Meselesinin İngiltere'nin Hint Yolu üzerindeki ve Akdeniz'deki konumunu sarsabilecek derecede bir öneme sahip olması, meselenin bu yönüyle ele alınmasını gerektirmektedir. Menemencioğlu, Almanya'nın konuya dâhil olarak denge unsuru olabileceği tahmininde bulunmuştur. Ona göre Türkiye, büyük devletlerarasındaki bu "hayat mücadelesinde çok müteyakkız bulunmak zaruretindedir". Menemencioğlu üçüncü olarak ise yine Habeş Meselesi çerçevesinde değerlendirmede bulunmuştur. Olası bir Habeş savaşı dolayısıyla, İngiltere'nin alacağı tedbirler arasında ilk sırayı Akdeniz'in alacağını düşünen Menemencioğlu, Akdeniz'in genişliği sebebiyle böyle bir durumda İngiltere için Türkiye'nin kollanması gereken bir yer haline geleceğini savunmuştur. $\mathrm{Bu}$ gelişmenin yaşanması halinde ise Adalar ve Boğazların durumlarını yeni bir değerlendirmeye tabii tutulmasının beklenebileceği düşünülmüştür. Menemencioğlu, beklediği inkişafin gerçekleşmesi halinde Türkiye'nin diplomasinin bütün inceliklerini kullanmak durumunda kalacağını ifade etmiştir (BCA, 30-10-0-0 / 219-476-5: 2-3). Menemencioğlu'nun ifadelerinden Türkiye'nin Boğazlarla birlikte İngiliz desteğiyle Ege Adalarının da Türkiye'ye iadesi konusunda beklenti içerisinde olduğu ortaya çıkmaktadır. Fakat buradaki nüans Türkiye'nin gerek Boğazlar gerekse Adalar konusunda firsat ortaya çıkmasını, Almanya veya İtalya cenahından değil İngiltere açısından değerlendirmesi olmuştur. Bu durum Türkiye'nin savaş başlamadan çok daha önce Almanya karşısında İngiltere'ye yakın olduğunu göstermektedir. Şüphesiz İngiltere'nin Milletler Cemiyeti'nde etkin olması da bu duruma imkân veren bir diğer gerekçe olmuştur.

Dördüncü değerlendirmesini Fransa-İtalya gelişmeleri olarak değerlendiren Menemencioğlu, Habeş Meselesinde Fransa'nın İtalya'yı destekliyor görünmesine rağmen İngiliz baskısı karşısında, Fransa-İtalya dostluğunun gevşeyeceğini düşünmüştür. Menemencioğlu, bu ihtimal doğrultusunda Türkiye Büyükelçilerinin İtalya-Almanya ilişkilerini incelemeleri gerektiğini vurgulamıştır. Menemencioğlu, oldukça tutarlı bir analizde bulunarak Fransa'nın İngiltere safina gireceğini, buna karşı ise İtalya ve Almanya'nın yakınlaşacağı tespitinde bulunmuştur. Türk dış politikası içinse oldukça önemli sayılabilecek bu gelişme karşısında Türkiye'nin yine Büyükelçileri vasıtasıyla bu yakınlaşmayı incelemelerini tavsiye etmiştir. Menemencioğlu'nun beşinci haşiyesi ise Balkanlar olmuştur. Meydana gelen gelişmeler karşısında Menemencioğlu, Balkan müttefikleri arasındaki işbirliğinin tam bir şekilde muhafazasının sağlanması gerektiğini belirtmiştir. Balkan

\footnotetext{
${ }^{5}$ Menemencioğlu'nun 1914 yılında Viyana Elçiliğinde III. Katip olarak başladığı mesleki kariyeri, maslahatgüzarlık, büyükelçilik, dışişleri bakanlığı pozisyonlarında, emekliliğine kadar sürmüştür, Bkz., Yücel Güçlü, Eminence Grise Of The Turkish Foreign Service: Numan Menemencioğlu, Ankara, 2002.
} 
müttefikleri arasında Türkiye'yi en çok ilgilendiren ülkenin Yugoslavya olduğu kaydedilmiştir. Hatta Menemencioğlu'na göre Yugoslavya'nın “iç ve dış siyasasını bir dakika gözden kaybetmemek zaruridir." Özellikle Yugoslavya'yı oluşturan milletlerin Yugoslav birliği hakkındaki görüşleri daima göz önünde tutulmalı ve Yugoslavya'nın merkezi otoritesi ile kuvvetini zayıflatacak yapılar tahlil edilmelidir. Menemencioğlu'na göre, diğer taraftan da "Sırp ve Bulgar milletleri" arasında beliren yakınlaşma arzusu en küçük detayına kadar gözden kaçırılmaması lazım gelen bir husustur. Bu konu hakkında Belgrad ve Sofya elçilerine çok iş düştüğünü söyleyen Menemencioğlu, Yugoslav yetkililerle kurulacak temaslarda, Yugoslavya'nın İtalya konusunda dostça tutum takınmasından çekinmesinin sık sık belirtilmesi gerektiğini ifade etmiştir (BCA, 30-10-0-0 / 219-476-5: 2-3).

Menemencioğlu, altıncı haşiyesinde ise İtalya'nın Güney Avrupa Paktı münasebetiyle Balkan blokunu bölmeye çalıştı̆̆ değerlendirmesinde bulunmuştur. Menemencioğlu'na göre sürecin bu şekilde işleyemeyeceği açıktır, bunun yerine Menemencioğlu, İtalya'nın "bütün Balkanlılarla bir pakt imzasına temayül göstermeleri[ni] daha muhtemel" bulmuştur. Fakat buna rağmen Menemencioğlu, yine de İtalya'nın Balkan bloku üzerindeki faaliyet ve tahriklerinin "hiç bir vakit gözden" kaçırılmamasının lazım geldiğini belirterek İtalya tehlikesi konusunda uyarıda bulunmuştur. Menemencioğlu'nun son olarak değindiği konu ise Almanya ile ilgili olmuştur. Dikkat çekici bir biçimde Avrupa' daki gelişmeleri 1935 yılı için daha ziyade, İtalya'nın yayılmacı siyaseti ekseninde değerlendiren Menemencioğlu, Almanya meselesini Türk dış politikası açısından ele almıştır. Mevcut durumda Türkiye-Almanya arasında bir değişiklik görülmediğini kaydeden Menemencioğlu, buna rağmen Avrupa'nın durumunu tehlikeli bulmuştur. Hitler Almanya'sının "seri adımlar atmakta" olduğu değerlendirmesinde bulunan Menemencioğlu, İngiltere-Almanya ilişkilerini de göz önünde tutarak iki hususa dikkat çekmiştir. Bunlardan ilki söz konusu hadiseler sebebiyle Türkiye'nin Almanya ile "normal dostluk" ilişkilerinin gevşemesine müsaade edilmemesi olmuştur. İkincisi ise Türkiye'nin Almanya aleyhindeki siyasi hareketlere açıktan açığa destek olmamasına özen göstermek olmuştur. Menemencioğlu, Türkiye'nin Almanya ile gelişen ticari ilişkilerini Almanya-Türkiye ilişkileri için takviye edici bir kuvvet olarak değerlendirmiştir. İki ülke arasında genişleyen ticaret hacmini, 1935 yılı sona ermeden yalnızca ihracatı boyutuyla yüz milyon Mark olarak gerçekleştiren Türkiye için, Almanya ihracatı genel ihracatın yüzde ellisini teşkil etmiştir. Menemencioğlu'na göre, Almanya ile yapılan ticaret, "yarınki tehlikelere karşı” Türkiye'nin iktisadî ve malî yapısını kuvvetlendiren önemli potansiyel, aynı zamanda kurutulmaması gereken bir kaynaktır (BCA, 30-10-0-0 / 219-476-5: 2-3).

\section{Başbakan İsmet İnönü'nün Habeşistan Meselesi Değerlendirmesi}

1935 yılı sona ererken Başbakan İsmet İnönü, Türk dış politikası ile ilgili olarak kendi el yazısı ile bir değerlendirme kaleme alarak Cumhurbaşkanı Mustafa Kemal Atatürk'e yollamıştır. Değerlendirme genel olmayıp daha ziyade 1935 yılının en önemli konusu olan İtalyan yayılmacılığı meselesi ile ilgilidir.

İnönü'nün gizli ibaresi ile yazdığı değerlendirme yazıs1, Atatürk'e bildirmek üzere telgrafla CHP Genel Sekreteri ve İçişleri Bakanı Şükrü Kaya'ya gönderilmiştir. İnönü yazısında, ajanslardan aldığı bilgi sonrasında Şükrü Kaya'ya dünya devletlerinin İtalya-Habeş meselesi için bir uzlaşma yolu aradığını ve aynı zamanda İtalya'ya petrol ambargosu kararına çalıştıklarını yazmıştır. İnönü, Dışişleri Bakanı Aras ile konuyu mütalaa ederken, İtalya-Habeşistan Meselesi bir neticeye vardırılacaksa, Akdeniz'in güvenliği meselesine de çare aranması gerektiği konusunu yeniden değerlendirdiklerini bildirmiştir. Hatta İnönü, bu konu ile ilgili olarak Aras'ın Avrupa'ya gidip gitmemesi gerektiğini dahi müzakere ettiklerini belirtmiştir. İnönü, yazısında Aras'ın İngiltere büyükelçisi ve diğer bazı kişilerle yaptı̆̆ 1 görüşmelerin hülasasına da yer vermiştir. Özet olarak İngiltere ve İtalya arasında bir uyuşmanın mümkün olmadığını ifade eden İnönü, bir anlaşma formülü bulunduğu anda Aras'ın Avrupa'da olması lazım geldiğini yazmıştır. Mevcut petrol ambargosu meselesi için ise Aras'ın Avrupa'ya gitmesine gerek görülmemiş̧ir. Aras, İngiltere'nin Ankara 
Büyükelçisi ile yaptığ 1 görüşmede, Akdeniz'in güvenliği meselesinin üzerinde durarak Akdeniz'de emniyetin sağlanmasının İngiltere, Fransa ve Balkanların faydasına olacağını ifade ettiği gibi gizli bir ihtirası olmaması halinde İtalya'nın da bundan faydalanacağını söylemiştir. İngiltere Büyükelçisi, İtalya-Habeşistan Meselesinin durumuna göre İtalya'nın durumunun belli olacağını söyleyerek, Habeş Meselesi mütalaa edilirken Akdeniz meselesinin de gündeme getirileceğini şahsi kanaati olarak söylemiştir (BCA, 30-10-0-0 / 45-290-45: 1-2).

İngiliz büyükelçinin petrol şirketlerinin ambargo uygulaması ile ilgili sözlerine de yer veren İnönü, özetle petrol yasağının kolaylıkla kabul olunacağını yazmıştır. İnönü, son olarak Şükrü Kaya'ya bütün bilgileri Atatürk'e arz etmesini ve gerekli direktiflerinin kendisine bildirilmesini istemiştir. Yazdıklarını "Vaziyetin bir raporu" olarak nitelendiren İnönü, telgrafın dişişleri bakanlığında kalmasını istemiştir (BCA, 30-10-0-0 / 45-290-45: 3). Atatürk'ün yanında bulunduğu sırada telgrafi alan Şükrü Kaya, durumu Atatürk'e arzetmiş, Atatürk ise İnönü’nün raporu doğrultusunda dikte ettirdiği notları vermek ve durumu görüşmek üzere Şükrü Kaya'nın en kısa sürede Ankara'ya doğru yola çıkacağını telgrafla bildirmiştir (BCA, 30-10-0-0 / 45-290-45: 1-2). 1935 yılı sona ererken İnönü’nün Atatürk'e gönderdikleri ve Atatürk'ün ciddi bir vakıa olarak konuyu ele alarak Şükrü Kaya'yı konuyu mütalaa etmek ve Atatürk'ün değerlendirmelerini sunmak üzere İnönü ve Aras'ın yanına göndermesi, 1935 yılı için en önemli sorunun İtalyan yayılmacılığının Habeşistan'ın işgali sonrasında Akdeniz'e dolayısıyla Türkiye'ye yansıyıp yansımayacağı meselesi olduğunu göstermiştir.

Türkiye, dış politikası açısından devletlerarasındaki menfaat çatışmasını takip ederek bu doğrultuda ortaya çıkacak uluslararası girişimlerde yer almak üzere refleks geliştirmiştir. Hükümet özellikle İtalya konusunda, devletlerarası hukuki süreçte aktif bir rol almak istemiştir. İtalyaHabeşistan Meselesini Akdeniz ve Balkanların güvenliği bağlamında ele alınmasını savunan Türk dış politikası aktörleri, II. Dünya Savaşı öncesinde İtalya'nın ortaya koyduğu tehdit karşısında ise İngiltere ile yakın bir diplomasi trafiği gerçekleştirmiştir. Dünyanın hızla II. Dünya Savaşı'na sürüklendiği bir dönemde Türkiye, uluslararası krize yol açan Habeşistan ve Akdeniz güvenliği meseleler karşısında İngiltere ile yakınlaşan bir dış politika anlayışı ortaya koymuştur.

\section{Sonuç}

1935 yılı Türkiye Cumhuriyeti'nin on ikinci yılını kutladığı bir tarih olmakla birlikte, Türkiye'nin tarihsel mirası itibariyle sahip olduğu diplomasi geleneği, on iki yıldan çok daha fazla bir tecrübeyi içerisinde barındırmaktadır. Bu sebeple 1935 yılında meydana gelen olayları Türkiye'nin nasıl değerlendirdiğini gözler önüne seren üç farklı rapor, Türk dış politikasının reflekslerini, II. Dünya Savaşı öncesinde tarihsel tecrübenin 1şığında değerlendirmektedir. Her ne kadar raporlarda ele alınan konular gündeme dairse de olayların kavranış ve analiz ediliş süreçleri, Türkiye'nin geçmişten miras aldığ 1 tecrübelerin bir değerlendirmesi olmuştur. Bu eksende Ali Türkgeldi'nin kaleme aldığı rapor, Numan Menemencioğlu'nun Türkgeldi'nin raporuna ek olarak yazdığ 1 ikinci bir rapor ve son olarak ise nispeten daha az kapsamlı ve de diğer iki rapordan bağımsız olan İsmet İnönü'nün raporu, Türkiye'nin 1935 yılında dış politikasını ortaya koymakta, Türkiye'nin öncelikli konularının neler olduğuna dair bir fikir vermektedir. Teknik bazda pek çok ortak ve odak noktası bulunmakla birlikte, raporların temel olarak kamuoyu için hazırlanmadıkları açıktır. Raporlar, dış politikanın teknik boyutuna ve diline yer veren mesleki çalışmalardır. Bu sebeple raporlar, Türk dış politikasının gelişmelere bakışını objektif bir değerlendirme sonucunda ele almıştır. Raporun sınırlarının devlet içerisinde kalacak olması, bağımsız kaleme alınmalarını gerektirmiştir, bu çerçevede ise Türkiye'nin beklenti ve endişelerine açık bir şekilde yer verilmiştir.

Kronolojik olarak ilk olan ve aynı zamanda en kapsamlı rapor olan Ali Türkgeldi'nin çalışması, 1935 yılının ilk aylarında başlayarak Temmuz-Ağustos ve hatta sonraki aylara kadar uzanan bir dönemi kapsamaktadır. Her ne kadar rapor, 1935 yılı sona erdikten sonra kaleme alınmamışsa da 1935 yılı içerisinde Avrupa ve Türkiye ile ilgili neredeyse tüm konulara yer 
ayrılmıştır. Türkgeldi raporunda, Türkiye açısından Avrupa'da meydana gelen olayları dikkatli bir şekilde incelemiştir. Çoğu kez Avrupa'daki elçiliklerden alınan raporlarla zenginleştirilen 1935 yılı raporu, politika yapıcılara olayları anlaması için rehber olmak üzere hazırlanmıştır. Bu sebeple Avrupa'da meydana gelen olaylar, Avrupa içi dengeleri üzerinden değerlendirilmiştir. Temel olarak Avrupa'yı Alman-İngiliz rekabeti içerisinde ele alan Türkgeldi, gelişmelere göre Türk dış politikasını konumlandırmak istemiştir. Türkgeldi'nin Avrupa'da yer verdiği irili ufaklı her olay, özü itibariyle Almanya ve İtalya ekseninde ele alınmıştır. Bu çerçevede Türkgeldi'nin raporu nezdinde, Türk dış politikasının mezkûr iki temel konuya odaklandığı görülmüştür.

İtalya'nın Habeşistan konusunda saldırgan bir politika izlemesi karşısında güvenlik kaygısı içerisine giren Türk dış politikası, Türkgeldi'nin ifadeleriyle Almanya-İtalya ittifakı beklentisi içerisinde olmuştur. Gerek Alman-İtalyan ittifakı beklentisi gerekse İtalyan'ın Habeşistan savaşı, II. Dünya Savaşı öncesinde Türk dış politikasının isabetli analizlerde bulunduğunu göstermektedir. Keza Türkgeldi'nin Habeşistan meselesini Balkanlar açısından ve İngiltere'nin Hindistan ve Afrika sömürgeleri açısından tahlil edişi bu isabeti ortaya koyan emarelerden olmuştur.

Ali Türkgeldi'nin raporuna ek olarak yazılan Numan Menemencioğlu'nun değerlendirmesinin de benzer bir tutum içerisinde olduğu görülmektedir. Menemencioğlu'nun tespitleri oldukça isabetlidir. Sovyet Rusya'nın artık pasif politikadan aktif politikaya geçtiğini düşünen Menemencioğlu, Türkiye'nin Sovyet Rusya ile ilgili gelişmeleri yakından takip etmesi gerektiğini ortaya koymuştur. Menemencioğlu'nun değerlendirmesi, SSCB'nin Türkiye için artık tehlike oluşturmaya başlayan bir komşu olarak dikkat çekmeye başladığını göstermektedir. Menemencioğlu, Sovyet Rusya yerine İngiltere'yi öne çıkartmıştır. Özellikle Habeş meselesinin İngiltere'nin etkisiyle Almanya-İtalya, İngiltere-Fransa bloklaşmasına yol açacağını düşünen Menemencioğlu, Türkiye'nin İngiltere ile uyumlu politika takip etmesiyle, Boğazlar ve Ege Adaları konularında fayda sağlanabileceğini düşünmüştür. Balkan konusuna ayrı bir önem atfeden Menemencioğlu, Türkiye'nin güvenliğinin Balkan ittifakından geçtiğini ve bu konuda en çok Yugoslavya'ya dikkat edilmesi gerektiğini ortaya koyarak, henüz 1935 yılında Türkiye'nin II. Dünya Savaşı sırasında izleyeceği siyaset hattını belirlemiş̧tir. Bu doğrultuda Menemencioğlu'nun belirttiği bir diğer husus ise devletlerarasında olan mücadelede Türkiye'nin teyakkuz halinde olması gerektiği tespitidir. Bu tespit, Türkiye'nin II. Dünya Savaşı yıllarında uyguladığı 'denge siyaseti'nin adeta bir ön değerlendirmesi olmuştur.

İsmet İnönü'nün raporu diğer iki rapordan bağımsız olmakla birlikte, aynı odak noktaya, İtalya'nın Akdeniz'de meydana getirdiği güven bunalımına yoğunlaşmışır. İnönü’nün raporunda Tevfik Rüştü Aras'ın İngiltere Büyükelçisi ile yaptı̆̆g görüşmeye yer vermesi, Türkiye'nin İtalya sorunun Milletler Cemiyeti ve İngiltere'nin riyasetinde çözülmesini istediğini göstermektedir. Almanya veya Rusya yerine İngiltere'yle yakınlaşan Türkiye'nin henüz 1935 yılında, II. Dünya Savaşı sırasında izleyeceği dış politika tavrını büyük bir oranda belirlediği görülmüştür. Buna göre Türkiye, Almanya, SSCB gibi büyük devletleri karşısına almamaya çalışırken aynı zamanda İngiltere'nin öncülüğündeki uluslararası anlaşmalara uygun bir biçimde meselelerin çözümüne taraftar olmuştur.

Avrupa'da devletlerin çıkarları doğrultusunda hızla kamplaştığı, Avrupa içinde ve dışında saldırganlıklarının arttığı bir dönemde Türkiye, raporlarla dünyada meydana gelen olayları değerlendirmiş ve Türkiye'nin takip etmesi gereken dış politikayı belirlemeye çalışmıştır. Türkiye'nin 1935 yılında dış politika raporlarda yer alan hususlar, II. Dünya Savaşı öncesinde ve sırasında Türkiye'nin izleyeceği siyasetin temel adımlarını oluşturmuştur. 


\section{Kaynakça}

\section{Arşiv Kaynakları}

Cumhuriyet Arşiv Kaynakları (BCA)

BCA, Fon Kodu: 30-10-0-0 / 219-476-5

BCA, Fon Kodu: 30-10-0-0 / 45-290-45

Taha Toros Arşivi

Dosya No: 191-Ali Fuat-Ali-Celal-Reşit Mualla-Nimet-Gülbin Türkgeldi.

\section{Kaynak Eser ve İncelemeler}

Akgün, M. (1994). Türk Dış Politikasında Bir Jeopolitik Etken Olarak Boğazlar. Türk Dış Politikasının Analizi (Der. Faruk Sönmezoğlu). Der Yayınları, 213-224

Başkaya, M. (2018). Atatürk'ün Genç Diplomatı ve Türkiye'nin Milletler Cemiyeti'ndeki İlk Daimî Temsilcisi: Cemal Hüsnü Taray'ın Hayatı ve Diplomatik Faaliyetleri. Tarih Okulu Dergisi, XXXIV, 667-685.

Bayur, Y. H. (1995). Türkiye Devletinin Dış Siyasası. Ankara. Türk Tarih Kurumu Basımevi.

Berber, E. (2008). Dönemin Dıș Politika Değerlendirmesi. Türk Dış Politikası 1919-2008. (Ed. Haydar Çakmak). Barış Platin Kitap, 236-246.

Bıyıklı, M. (2008). Kemal Atatürk ve Türkiye Cumhuriyeti Devleti’nin Ortadoğu'ya Yönelik Siyasî ve Askerî Yaklaşımları ve Politikaları (1917-1938). Türk Dış Politikası -Cumhuriyet Dönemi- 2. (Ed. Mustafa Biyıkl1). Gökkube, 315-349.

Cemil, K. (2013). Türk - Alman Illişkileri (1923-1939). Türk Tarih Kurumu.

Dışişleri Bakanlığı. (1959). Hariciye Vekâleti Yıllığı.

Emecen, Feridun (2012). Varna Muharebesi. Türkiye Diyanet Vakfi İslam Ansiklopedisi (42), 527530.

Fahir A. (t.y.), 20. Yüzyıl Siyasi Tarihi 1914-1995. Alkım Yayınevi. 14. Bask1.

Gönlübol, M. \& C. Sar (1997). Atatürk ve Türkiye’nin Dış Politikası (1919-1938). Atatürk Kültür, Dil ve Tarih Yüksek Kurumu Atatürk Araştırma Merkezi.

Güçlü, Y. (2002). Eminence Grise Of The Turkish Foreign Service: Numan Menemencioğlu.

Gürün, K. (2010). Türk-Sovyet Ilişskileri (1920-1953). Türk Tarih Kurumu Basımevi, (Tıpkı Basım).

Hale, W. (2003). Türk Dış Politikası 1774-2000, (Çev. Petek Demir). Mozaik Yayınevi.

Kurtcephe, İ. \& A. Beden (2008). Türkiye Cumhuriyeti Devleti'nin Musul-Kerkük Politikası. Türk Dış Politikası -Cumhuriyet Dönemi- 2. (Ed. Mustafa Bıyıklı). Gökkube, 420-511.

Sonyel, S. R. (2003). Türk Kurutuluş Savaşı ve Dış Politika II. Türk Tarih Kurumu Basımevi.

Soysal, İ. (1999). İki Dünya Savaşı Arasında Avrupa'da Kuvvet Dengeleri ve Barışçı Türkiye, Çağdaş Türk Diplomasisi: 200 Yıllık Süreç. Türk Tarih Kurumu Basımevi, 293-295.

Turan, R. (1998). Misâk-1 Millî ve Atatürk'ün Lozan Sonrası Hedefleri. Misâk-ı Millı̂ ve Türk Dlş Politikasında Musul, Kerkük ve Erbil Meselesi Sempozyumu. Ankara. Atatürk Araştırma Merkezi, 51-56.

Uçarol, R. (2000). Siyasi Tarih (1789-1999). Filiz Kitabevi.

Yılmaz, M. S. (2017). Atatürk Dönemi Türk Dış Politikası (1923-1938). Türk Dış Politikası (18301989). (Ed. Serkan Kekevi, Yunus Emre Tekinsoy, İsmet Türkmen). Berikan Yayınevi, 419468. 